\title{
Дальневосточная политика западных держав в восприятии русской либеральной общественности по материалам столичной периодической печати (1895-1902 гг.)
}

\begin{abstract}
Аннотахия: После поражения Китая в войне с Японией в 1895 г. дальневосточная политика великих держав активизироваласъ. События и прочессы, происходившие в регионе, вызвали повышенный интерес общественности. На этот интерес откликнулась пресса, отчасти формируя, отчасти выражая бытовавшие мнения. В статъе на материалах «большой» столичной либеральной печати исследуются характерные для образованнъхх кругов русского общества взгляды на ключевых западных участников китайского кризиса, на их политику и характер взаимоотношений с Россией. Анализ публикаиий газет и журналов позволяет автору сделать выводо том, что, несмотря на неоднородность представленных точек зрения, отмечается наличие обших тендениий: положительное или нейтральное освещение политики Франиии, сложное отношение к конкурентам (Германии и Америке) и в челом негативное - к Британии. Нередко по степени близости взаимоотношений с Англией оченивалась мера опасности того или иного соперника. В то же время приоритетными считались интересы мира и общеевропейской солидарности, ради которых державам следовало стремиться к согласию.
\end{abstract}

Ключевые слова: Англия, «Вестник Европъ», Герлания, дальневосточная политика, Китай, либеральная пресса, общественное мнение, «Русские ведомости», Франиия, США.

Annotation: After the defeat of China in the war with Japan in 1895, the Great Powers initiated their Far Eastern policy. The events and processes happening in the region heightened the public's interest in it. The press reacted to this interest, in part forming, in part expressing the existing opinions on the subject. The article, based on the material from the capital's "big" liberal press, examines the general viewpoints of Russian society's educated circles towards key Western actors in the Chinese crisis, their policy and the nature of their relationship with Russia. The analysis of the publications from newspapers and journals allows the author to come to the conclusion that despite the disparity of the represented outlooks, broad tendencies existed: a positive or neutral presentation of France's policy, a complicated relation towards rivals (Germany and America), and an overall negative perception of Britain. Often the degree of danger of one or another rival was assessed depending on the closeness of their relationship with England. At the same time, the primary interests put forward were peace and panEuropean solidarity, for the sake of which all powers should strive for agreement.

Key words: England, "Vestnik Evropy", Germany, Far East policy, China, liberal press, public opinion, "Russkie Vedomosti”, France, USA.

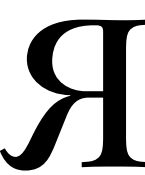

поно-китайская война 1894-1895 гг. и последовавшие за ней события вызвали повышенный интерес русского общества к процессам, происходившим на Дальнем Востоке, и к их ключевым участникам. В представленной статье рассматриваются материалы, размещенные в «больших» либерально ориентированных периодических изданиях Санкт-Петербурга и Москвы. Публикации в прессе интересны, в частности, тем, что отражали взгляды преимущественной аудитории (столичных образованных слоев населения) и во многом формировали представления данной части русского общества о дальневосточной политике, о союзниках и соперниках России.

После поражения Китая, обнаружившего собственную слабость, великие державы начали ускоренный раздел страны на сферы влияния. Наряду с экспортом товаров главной формой экспансии стал экспорт капиталов. Державы навязывали займы и добивались концессий. Регионом экономического преобладания Англии сделались Южный Китай, а также провинции среднего течения Янцзы, сферой влияния Японии - провинции нижнего течения Янцзы, Франция стремилась утвердиться в провинциях 


\section{Исторический журнал: научные исследования № 6 (24) • 2014}

DOI: 10.7256/2222-1972.2014.6.14860

Юга, Германия установила контроль над Шаньдун. Интересы России были сосредоточены в Маньчжурии, где она соперничала с Японией. В июне 1900 г. в «Русских ведомостях» автор под псевдонимом «Х.» отмечал, что Англия относилась к России «ревниво и подозрительно» [125]. Соединенные Штаты держали себя «настороже», опасаясь преобладания Европы на крайнем Востоке. Франция оставалась дружественной.

Франция была союзным государством. Сфера ее влияния не пересекалась со сферой влияния России. Поэтому практически все отзывы о Франции были положительными или нейтральными. Согласно мнению, выраженному на страницах авторитетнейшей либеральной газеты «Русские ведомости», Россия, «занимавшая такое же положение на севере Китая, как и Франция на юге», была «естественным союзником» Франции; обеим приходилось соперничать с Англией [127]. Доброжелательность по отношению к Франции выразилась среди прочего в положительных отзывах постоянного корреспондента газеты В. В. Корсакова о деятельности в Китае католических миссионеров, которые в отличие от протестантов «заслуживали глубокого уважения» [149].

Еженедельная газета журнального формата «Неделя» (придерживавшаяся либерально-народнического направления) в качестве одного из достижений предыдущего царствования называла союз с Францией, на который «можно опереться» [115].

В 1895 г. «Вестник Европы» сообщал, что франко-русский союз «действует успешно и начинает приносить пользу обеим сторонам» $[9$, 361-362]. Солидарность проявлялась «в разных краях мира, где обе державы имеют какие-нибудь интересы». В частности, обе союзницы извлекли выгоду из тройственного вмешательства, которое позволило ограничить требования Японии к побежденному Китаю. Франкорусская дружба была «одним из важнейших элементов общей европейской политики»; «обоюдная выгодность» служила гарантией прочности $[10,397]$.

Редакция «Новостей и Биржевой газеты» также отзывалась о франко-русском союзе с симпатией: совместные действия обеспечивали «как материальные интересы России, так и ее личное достоинство» [76]. «Новости» приветствовали Францию как «дорогого друга», страну «союзницу в горе и в радости» [82]. В 1902 г. редакция «Новостей» уверяла: «...давно уже мы не знали такого чувства внешней безопасности, какое испытываем теперь, когда устранены всякие сомнения относительно твердой решимости России и Франции защищать общими силами взаимные интересы» [2]. Редакция отмечала, что «в китайском вопросе» франкорусский союз проявил «жизнеспособность и несомненную пользу для обеих великих держав» [36]. Интересы Франции были сосредоточены в Южном Китае, что делало союз «естественным и практичным» [90]; кроме того, Франция была «естественной соперницей» Англии [89].

Постоянный внешнеполитический обозреватель ежемесячного журнала «Русское богатство» (либерально-народнической направленности) С. Н. Южаков ожидал от франко-русской комбинации «установления европейской безопасности», «восстановления идеи солидарной Европы» и «некоторого взаимного содействия в колониальных делах» [161, 131].

Газета «Курьер» отмечала, что Россия и Франция действовали на Дальнем Востоке «совместно, поддерживая каждая требование другой» [54]. Редакция писала, что «в случае осложнений на Дальнем Востоке Россия имеет верную союзницу в лице Франции...» [59]. Согласно «серьезным английским органам печати» эти страны заключили, «с тех пор как мир стоит, единственный действительно прочный союз».

Судя по материалам, опубликованным в «Русских ведомостях», Берлин придерживался нейтралитета в отношении как России, так и Англии. В обзоре событий 1895 г. редакция утверждала, что при всех осложнениях Германия «считала своей задачей содействовать сохранению европейского мира» [22]. Стремления ее были направлены «к поддержанию дружбы со всеми соседями, особенно же с нашим отечеством». В дальневосточной политике германская дипломатия руководствовалась намерением «соединить верность тройственному союзу с добрыми отношениями к России» [23].

В 1898 г. в обзоре заседания рейхстага специальный корреспондент «Русских ведомостей» акцентировал внимание на речи статс-секретаря иностранных дел Б. фон Бюлова, в которой тот проповедовал принцип нейтралитета. Ввиду слухов о возможном занятии Россией Порт-Артура Бюлов заявил, что интересы России и Германии не пересекались, поэтому если бы Россия «приобрела могущество» в Азии, Германия стала бы смотреть на это «глазами старых друзей, с искренней симпатией и без капли зависти» [148]. 
Впрочем, точно так же Германия была «далека от мысли выступать против Англии». По вопросу о влиянии России в Маньчжурии Германия заняла нейтральную позицию: в 1901 г. Бюлов уверял, что между Германией и Россией не было острых разногласий, судьба Маньчжурии была безразлична Берлину [119]. В то же время Германия не имела ничего против англо-японского союза [158].

В отношении Англии Германия, как правило, придерживалась нейтралитета, Лондон же старался вовлечь ее в орбиту своего влияния. В ноябре 1898 г. адмирал Ч. Бересфорд произнес речь, в которой сетовал на падение британского влияния в Китае и высказывался в пользу союза Англии, Америки, Японии и Германии для поддержания политики «открытых дверей» и неприкосновенности Китая [27]. Несмотря на все попытки, создать себе союзника в лице Германии «никак не удавалось» [44]. У Берлина не было «ни повода, ни желания впутываться в возможные несогласия между лондонским и петербургским кабинетами». По утверждению редакции «Русских ведомостей», Германия держалась «очень корректно» по отношению к обеим странам, однако «едва ли была бы очень огорчена» из-за ссоры России с Англией [46].

«Новости» не раз упоминали об успешности совместных действий России, Франции и Германии, считали важным взаимное сотрудничество и в то же время питали к последней недоверие. Во время тройственного вмешательства была отмечена независимость германской позиции: та выступила «не для того, чтобы оказать услугу России (она слишком своекорыстна для этого!), но потому лишь, что она касается торговой конкуренции японцев в Китае» [126]. Редакция не обошла вниманием тот факт, что «общественное мнение в Германии до сих пор еще не убедилось в целесообразности этой политики в японском вопросе...» [80]. В статье «Могущество Англии» В. Модестов мимоходом заметил, что, возможно, «за свою заносчивость» придет время поплатиться и Германии, которая «никого не боится, кроме Бога» [151].

В редакционной статье по случаю приема российского императора в Бреславе «Новости» выражали сомнение по поводу уверений германской прессы в том, что Германия «оказала ряд услуг и поддержку русской политике»; однако «Новости» признавали, что эта страна «за все время своего существования поддерживала мирные отношения с Россией» [81]. Редакция соглаша- лась с официальным изданием «Reichsanzeiger» в том, что «Германия и Россия могут в мирном, подчас совместном труде посвящать себя выполнению культурных задач». «Новости» полагали, что «всякий раз, когда в дело будут замешаны мировые интересы обеих держав, соглашение между ними будет не только возможно, но и необходимо». Как Петербург, так и Берлин были заинтересованы «в сохранении мира в Европе», чтобы иметь возможность обеспечивать свое влияние «на Дальнем азиатском Востоке и во всем мире». Именно поэтому следовало «дорожить всяким проявлением дружественных и добрых соседских отношений между Россией и соседними империями».

В октябре 1897 г. редакция «Новостей» замечала, что миролюбие Германии было несомненным: «Она так много взяла, что не желает лишиться приобретенного в новой войне. Она хочет развиваться мирно и богатеть» [83]. Последовавший вскоре захват немцами Циндао возмутил редакцию: порт должен был отойти к России [86]. Германия могла бы захватить Самсахскую бухту, но она предпочла не конфликтовать с Англией. После этого редакция видела расстановку сил так: с одной стороны, на Дальнем Востоке приходилось иметь дело с Китаем и Японией, с другой - «вести борьбу с усилиями Англии и Германии» [84]. Так, редакция объединила Германию с Англией и уравняла опасность этого альянса с будоражившей в то время умы «желтой угрозой». Впрочем, в другой статье, когда обсуждалась возможность союза Англии и Японии, Германия была включена в одну группу держав («не объединенных договором, но сознающих общность своих интересов») с Францией и Россией [116].

В 1899 г., после того как общественность примирилась с захватом Циндао благодаря занятию русской эскадрой Порт-Артура, в «Новостях» утверждалось: «Если бы понадобилось в двух-трех словах определить русско-германские отношения, то мы бы сказали, что эти отношения - добрые, дружественные и соседские» [96]. Прежде всего между двумя странами существовала «тесная экономическая связь»; затем «в известных случаях» возможны были совместные действия. После тройственного вмешательства «политика России, Франции и Германии шла в одном направлении». В 1899 г. русско-германские отношения «упрочились» и «приняли еще более дружественный характер» [6]. Осенью 1900 г. В. Верещагин признавал, что «если не по 


\section{Исторический журнал: научные исследования № 6 (24) • 2014}

DOI: $10.7256 / 2222-1972.2014 .6 .14860$

Европе, то по Китаю» Германия была союзницей России [131].

При этом в «Новостях» звучали и слова о потенциальной опасности Германии. В 1897 г. редакция утверждала, что усиление Германии в Китае было не в интересах России [85]. Coгласно сведениям корреспондента немецкая колонизация набирала обороты, торговая деятельность составляла «солидную конкуренцию» англичанам и японцам [124]. М. Энгельгардт замечал, что уровень богатства и развития промышленности, военное могущество, численность и скорость роста населения, политический вес Германии не соответствовали ее малым колониальным владениям [160]. Это делало ее «опаснейшим соперником» и «неизбежно» должно было привести к столкновению с Англией и Россией. Е. Оболенский в июне 1900 г. и вовсе предупреждал о том, что «несмотря на взаимное отвращение», отношения Германии и Англии постепенно улучшались в противовес России [152]. Впрочем, на заключение в 1900 г. англо-германского соглашения редакция отреагировала без эмоций, назвав «соглашения вроде англо-германского» второстепенными (основное значение имели совместные действия, ведшие к «открытию» Китая [104]). В ноябре 1900 г. редакция все еще допускала «соглашение» между Россией, Францией и Германией, подобное союзу 1895 г. [105].

Схожей позиции по отношению к Германии придерживалась «Неделя». В 1895 г. в газете сообщалось, что Англия и Германия (страны были помещены в одном ряду) «остались крайне недовольны руководящей ролью России» в окончании войны и в получении Китаем займа [115]. Германии, оспаривавшей английское влияние на Китай, русские успехи были «крайне неприятны». В то же время говорилось о необходимости мирных взаимоотношений. Упоминалось, что в прошлое царствование Россия приобрела «не только удовлетворительные отношения к Германии, Англии и Австро-Венгрии, но и союз с Францией <...> Умение поддержать мир даже с враждебными соседями - это выгода, и весьма реальная, умение не нажить врагов, особенно сильных, - тоже выгода...». Говорилось и об английском влиянии на Германию. В статье о «безусловно агрессивном» англо-японском союзе было упомянуто, что «немецкая пресса оценивает его снисходительно, что объясняется слухами, будто бы Германия получает путем сепаратного договора приличную мзду за свое согласие...» [52].
В «Курьере» упоминались как успешный опыт взаимодействия с Германией, так и опасность немецкой конкуренции. В декабре 1897 г. в передовой статье было отмечено «дружественное» отношение Берлина к России [52]. Державы преследовали на Дальнем Востоке «солидарную политику» [53]. Л. А. Богданович с сожалением констатировал, что из-за франкогерманского антагонизма нечего было и мечтать «о великом континентальном союзе ранее полувека» [5]. При этом Германия не собиралась «таскать для Англии каштаны из огня» [58]. По поводу взаимодействия с Китаем в 1900 г. один из ведущих публицистов «Курьера» В. А. Гольцев писал, что «дружественный образ действий России и Германии вместе с Францией на Дальнем Востоке принесет и европейской цивилизации, и непосредственным интересам нашего отечества в данном случае еще больше пользы, чем это тройственное воздействие оказало после японо-китайской войны» [147].

Это не отменяло конкуренции: германское «колониальное могущество» делалось «грозным» [65]. В 1900 г. об Австро-Венгрии говорилось, что та становится для России «могущественным конкурентом, пожалуй, не менее сильным и стойким, чем Германия» [64]. Последняя же быстро расширила свои колонии и подбиралась к русскому Дальнему Востоку, стараясь «связать там принадлежащие России области неразрывными экономическими узами с Германией» [65]. Ее военная опасность пока не казалась чересчур грозной. Отправка немецкой эскадры в Циндао в 1897 г. вызвала у редакции недоумение [40]. Идея о том, что Германия, дружественно относясь к России и Франции, была намерена «застращать» их броненосцами, была названа маловероятной.

В «Русской мысли» отмечалось недоброжелательство Берлина. В апреле 1898 г. редактор журнала, вышеупомянутый В. А. Гольцев, утверждал, что немецкая печать «постоянно твердила об антагонизме русских и английских интересов» - в частности в Китае; противостояние это шло на пользу Германии $[137,179]$. По поводу слухов об англо-германском союзном договоре в декабре 1898 г. Гольцев писал, что такой союз был бы невыгоден для России - помимо прочего, на Дальнем Востоке [139, 233]. Процитировав по вопросу русского-английского соглашения 1899 г. «Курьер», Гольцев добавлял, что распря с Англией «могла только послужить на пользу государствам, враждебным России и 
Англии. Справедливость этой мысли можно видеть хотя бы из отношения германской печати, которая всячески старается посеять недоверие между обеими державами...» $[140,185]$. В 1900 г. Гольцев замечал, что Россия пользовалась «особым недружелюбным вниманием со стороны держав, которые считают, что усиление русского влияния на Дальнем Востоке грозит их интересам. По преимуществу это следует сказать об Англии и Японии. Германия держится очень корректно в настоящем вопросе, но и она едва ли была бы очень огорчена ссорой между Россией и Англией» [142, 212].

По поводу карательной экспедиции фельдмаршала Вальдерзее, имевшей целью подавление восстания в Китае, Гольцев приводил прогноз Е. Рихтера, согласно которому «колониальные приобретения и приключения принесут Германии труднопоправимый вред, и, кажется, в этом отношении он прав. Суд истории покарает Германию и за ее захваты в Китае, за зверскую расправу с китайцами» $[135,210]$. В целом же редактор был далек от «зложелательства по отношению к германскому народу»: «В некоторых отношениях современная Германия безусловно необходима для правильного развития всего человечества. Конечно, мы имеем в виду не германский милитаризм и не остатки бюрократии, а германскую науку, широкую постановку многих общественных вопросов, серьезную и независимую печать» [144, 273-274].

В «Вестнике Европы» проводилась мысль о том, что Россия и Германия сохраняли «традиционную дружбу» [12, 382]. В 1898 г. анонимный политический обозреватель (предположительно Л. 3. Слонимский) утверждал, что Германия была в стороне от воинственных планов, подавала «британскому льву» пример миролюбия и «весьма сдержанно» относилась к намекам на желательность сближения с Англией: «Германия отлично устраивает свои дела и соблюдает свои интересы, не возбуждая никаких щекотливых международных споров <..> немцы убедились на опыте, что политические и национальные интересы гораздо вернее и спокойнее обеспечиваются неустанной мирной работой, чем лихорадочными вооружениями и дипломатическими эффектами...» [13, 786]. В июле 1900 г. в журнале упоминалась «традиционная дружба» с Германией [15, 372-373]. В то же время осторожно отмечалась и экспансивность Германии. По поводу занятия Циндао говорилось, что «Германия, с ее возрастающими избытками культурного и трудолюбивого населения, несомненно нуждается в колониях, и ее энергические усилия к созданию военного флота имеют в этом свое оправдание» $[11,400]$.

В 1899 г. в «Русском богатстве» С. Н. Южаков утверждал, что немецкая политика «стояла все время на почве реальных интересов, не задаваясь никакими общими идеями, и своей наиболее выраженной целью ставила колониальное расширение» $[168,117]$. Германия «искусно поддерживала добрые отношения с Россией» [162, 114]. В то же время Англия стремилась вовлечь потенциальную союзницу в свою орбиту. В 1899 г. стало очевидным «некоторое англо-германское сближение»; его развитие было «желанным для государственных людей Лондона», но пока мало интересовало Берлин. В ноябре 1900 г. Южаков трактовал англо-германское соглашение как естественное объединение: обе державы стремились к господству в Китае, вели агрессивную политику и нуждались «во взаимной поддержке против более умеренно настроенных других держав» [165, 155-156].

Несмотря на существующие противоречия, необходимо было выстраивать мирные взаимоотношения. Не зря на страницах «Русского богатства» цитировался «один из талантливейших политических публицистов Франции» Г. Депасс: он утверждал, что любая держава - суть «ничто, если изолирована. Только Европа в ее целом имеет реальное существование, и всякая война между ее различными членами является <... самоубийством» [165, 144-148]. Южаков надеялся, что Германия разделит эти идеи и «преступные раздоры, совершенно справедливо приравниваемые Депассом к самоубийству, отойдут в область прошлого». В феврале 1902 г. Южаков отметил, что в маньчжурском вопросе Германия «не пожелала дальше играть в руку своей якобы союзнице...» [166, 122]. «Очевидно, Германия очень дорожит дружескими отношениями с Россией, что при консервативном и монархическом характере правительств обеих держав вполне естественно и понятно».

О США пресса отзывалась похожим образом: это был потенциальный соперник, до поры сохранявший относительный нейтралитет; взгляды расходились в основном в оценке степени близости взаимодействия Лондона и Вашингтона. Позиция «Русских ведомостей» по отношению к Соединенным Штатам была сложной. По утверждению редакции, США имели важные интересы на Дальнем Востоке и намере- 


\section{Исторический журнал: научные исследования № 6 (24) • 2014}

DOI: $10.7256 / 2222-1972.2014 .6 .14860$

вались вести там деятельную политику [41]. Влияние на направление этой политики стремилась оказывать вездесущая Англия. «Times» указывала на «двух естественных союзников Англии на Востоке» - Японию и Америку [31]. Цитируемая английская печать выражала надежду на то, что США будут сотрудничать с Лондоном [41]. В декабре 1898 г. «Русские ведомости» отметили, что «старания англичан втянуть Соединенные Штаты в китайский вопрос, по-видимому, увенчиваются успехом» (бывший посланник США в Сиаме заявил о необходимости проводить политику «открытых дверей», чтобы предупредить раздел Китая, в результате которого доступ англо-американской торговли в Китай мог прекратиться) [28]. В октябре 1899 г. США потребовали от России, Франции и Германии сделать заявления, обеспечивающие целость Китая и политику «открытых дверей»; редакция утверждала, что американское правительство действовало с ведома британского [68]. «Русские ведомости» уделили внимание даже резолюции ассоциации бумагопрядильщиков южных штатов [29]. В ней правительству рекомендовалось действовать заодно с Англией и Японией, ратовавшими за неограниченную торговлю в Китае. Резолюция высказывалась в пользу увеличения военного флота до таких размеров, которые давали бы ему возможность защищать интересы американской торговли «во всех частях света». По «маньчжурскому вопросу» США активно выступали против России на стороне Англии и Японии [32]. Америка форсировала политику «открытых дверей» с целью сохранить за собой торгово-промышленные выгоды, которыми она пользовалась в Маньчжурии.

«Новости» отмечали нейтральность позиции США. Во время японско-китайской войны, невзирая на прояпонские общественные симпатии, Вашингтон не оставил «строжайшего нейтралитета, несмотря на запросы из Лондона и старания японских дипломатов» [74]. Причиной стало решение придерживаться традиционной политики невмешательства. В декабре 1897 г. «Новости» сообщали, что, несмотря на «попытки английских политиканов» организовать союз в противовес «франко-русско-германскому союзу», Америка не поддалась на уговоры, найдя, «что с одной Кубой хлопотать довольно» [89]. В 1900 г. М. Энгельгардт замечал, что направление политики США «еще не определилось» [161]. Е. Оболенский объяснял, что товарообмен Америки с Китаем по величине был на вто- ром месте после английского, американцы выступали за свободные порты, и в силу этих причин чувствовалось «их охлаждение относительно России» [153]. В 1901 г. по поводу слов Т. Делькассе о близости интересов России, Франции и США редакция замечала, что такая комбинация была бы «весьма полезна для обеспечения равновесия», однако «политика С. Штатов в китайском вопросе до сих пор отличалась такой переменчивостью, что возлагать особенно серьезные надежды на С. Штаты вряд ли возможно» [106].

«Курьер» также отмечал, что Америка держалась в дальневосточной политике особняком. Характерно, что в конце мая 1900 г., в преддверии военных действий в Китае, «Курьер» задался вопросом, в «какое положение по отношению к остальным державам станет Америка» [35]. США были «менее всех склонны» к совместным действиям. Агрессия со стороны Америки едва ли вызвала бы удивление. В 1898 г. редакция «Курьера» отмечала, что политика США «все больше и больше направляется в сторону колониальных приобретений». Соединенные Штаты собирались укрепить свое положение в южной части океана, чтобы иметь возможность в любой момент «сосредоточить в любом пункте Тихого океана внушительные сухопутные и морские силы...» [58]. У европейских держав возникала необходимость считаться с США, «которые в последнюю войну с Испанией показали, что они ни перед чем, даже перед войной, не останавливаются для достижения намеченных ими целей». Так, державы, «интригующие друг против друга на Востоке, не заметят, какой серьезный противник вырастает, если уже не вырос, в Тихом океане».

Экономическое завоевание уже началось. В обзоре прессы были приведены сведения из статьи «одного из самых энергичных и образованных империалистов» Д. Барретта, выступавшего за «агрессивную политику» на Дальнем Востоке [39]. Он указывал на то, что в Китае, который мог «сделаться даже главным рынком», Вашингтон ожидали «огромные доходы». По торговому значению США были «третьей властью» и имели «больше прав послать войска, чем Россия, Франция или Германия». Американские производители и торговцы были «грозным противником» русской торговли в Китае [120].

Поводом для опасений служила и склонность Вашингтона к совместным действиям с Великобританией. Л. А. Богданович упоминал, что Англо-бурская война «выдвинула на первый 
план другое грозное для всех континентальных держав явление»- сближение англосаксонской расы [5]. По поводу революции на Филиппинах автор писал: «Пусть человечество знает, что обе эти нации англосаксонского происхождения, претендующие идти во главе цивилизации, идут на самом деле на помочах спекулянтов и авантюристов, громко именующих себя по обе стороны океана “империалистами”». Основания для беспокойства по поводу сближения были. В 1898 г. в «Курьере» было приведено интервью «Daily Mail» с председателем иностранного департамента сената [60]. Интервьюер утверждал, что английские и американские интересы на Дальнем Востоке шли «совершенно параллельно» и им следовало придерживаться одинаковой политики. Он выступал за союз с Англией и Японией для защиты от России, Германии и Франции, которые захватили «выгоднейшие отрасли торговли».

От выбора США зачастую зависел баланс сил. В 1899 г. в «Русской мысли» В. А. Гольцев приводил слова лорда Бересфорда: с целью уравновесить русское влияние на Дальнем Востоке Англия должна была «искать союзников в лице Германии, Соединенных Штатов и Японии» [141, 225]. В 1901 г. Гольцев писал о том, что в связи с возможностью англо-германского союза «весьма важно» было, какую позицию займут США [145, 202]. Англосаксонские страны не всегда действовали в согласии. Так, в 1901 г. отмечалось, что США не собирались отдавать Китай «в исключительную эксплуатацию Англии и Германии» $[136,210]$. В 1902 г. было упомянуто, что сближение Германии с США было «совсем не в английских интересах» [146, 223].

В «Вестнике Европы» сообщалось о независимости позиции США. В 1900 г. в международном обозрении утверждалось: «Всякий знает в наше время, что Англия находится в постоянном антагонизме с Россией в области восточных, и в частности китайских, дел <...> Соединенные Штаты также преследуют свои особые интересы, нередко противоположные британским» [17, 804-805].

В 1895 г. «Неделя» отмечала слухи о тайном соглашении между Англией, Японией и Соединенными Штатами [47].

В 1899 г. С. Н. Южаков в «Русском богатстве» писал, что США оказались на распутье [167, 113-114]. Если бы, «как на то имеется больше шансов», Америка взяла курс на завоевания и «тесную солидарность с Англией», это стало бы началом «нового периода всемирной истории». Если бы Америка показала пример «власти над собой» и «подчинения моральному долгу», это также стало бы «поворотным пунктом истории», послужив будущему разоружению. В Вашингтоне, как и в Лондоне, были «сосредоточены нити, приводящие в движение политическую машину современного мира». Америка выступила «в качестве нового фактора мировой политики»; «все желали видеть ее на своей стороне» [167, 123]. Южаков рассуждал, что «американская плутократия не со вчерашнего дня чувствует склонность к Англии, но постоянное соперничество двух держав в разных пунктах Нового Света продолжало питать традиционную неприязнь американского народа к Англии...». Наконец англосаксонские государства решились на то, чтобы проводить общую политику на Дальнем Востоке. Сближение было неполным: так, в 1902 г. комбинация англо-японского союза могла бы «превратиться в триумфальное шествие, если бы удалось соблазнить в союз Соединенные Штаты...». Если бы дело зависело только от министра иностранных дел США, объединение было бы неизбежным, однако общественное мнение было «малоблагоприятным английскому союзу и еще менее благоприятным “желтой” дружбе». «Не решаясь прямо примкнуть к союзу», Америка взялась действовать в параллельном направлении и адресовала России ноту против русскокитайского соглашения о Маньчжурии. Южаков отмечал «движение к новой группировке, выразившееся в англо-японском соглашении, германо-американском сближении, ноте о Маньчжурии Соединенным Штатам и пр.»

Политика Англии вызывала в столичной либеральной прессе многочисленные негативные отклики. Пожалуй, наиболее враждебно были настроены «Русские ведомости». При относительной нейтральности проявлений редакционной позиции неприязнь к «коварному Альбиону» бросалась в глаза.

Все успехи в «открытии» Китая для британской торговли были достигнуты насилием [33]. Казалось, англичане делали все, чтобы вызвать к себе неприязнь местного населения. Не раз отмечались жадность, эгоцентризм и лицемерие британских политиков. Каждое новое правительство объявляло, что оно не собиралось увеличивать территориальные владения, и сразу же после этого делались новые приобретения [67]. Англичане желали слишком многого, признавая право на экономическое и политическое 


\section{Исторический журнал: научные исследования № 6 (24) • 2014}

DOI: 10.7256/2222-1972.2014.6.14860

влияние только за собой. По едкому замечанию редакции, заключение соглашения между Англией и Россией о разделении сфер влияния в Китае было бы разумным шагом, однако его затрудняло то, что англичане «усматривали свои “жизненные интересы” во всех частях Поднебесной империи» [43].

Апогей обвинений был достигнут в статье И. Ф. Василевского [130]. Автор утверждал, что во всей Европе росло движение, враждебное Англии; тем естественнее была неприязнь России, которой она «всегда становилась поперек дороги». Великобритании было «вовсе не знакомо чувство альтруизма». Это была страна «самого крайнего, самого жестокого и бессердечного эгоизма». Жизнь в самой Англии рисовалась мрачными красками: нигде человек «так не любит себя и так не жесток к другому, как в Англии»; «нигде не было такой страшной борьбы за существование, нигде она не ведется так трагично и беспомощно». Что и говорить об английской внешней политике, которая была всецело основана на «крайнем эгоизме». Англичан волновали исключительно собственные нужды. «Интересы Англии - это святая святых <..> Предназначение земного шара - быть под верховной властью Великобритании». У нее была «только одна цель» - накопление богатств, изъятых у других наций. Поэтому, уверял автор, «Европа радуется огорчениям и неудачам нации эгоистов, привыкших победоносно сокрушать все встречающиеся на их пути преграды силой своих денег или своего оружия».

Как утверждала редакция, Россия пользовалась «особенно недружественным вниманием» со стороны Англии, которая считала, что усиление русского влияния на Дальнем Востоке угрожало ее интересам [46]. Согласно приведенным в «Русских ведомостях» словам адмирала Э. Сеймура у Великобритании было «три великих соперника», первым была названа Россия [157]. Англия вызывала осложнения в Китае ради противодействия ее успехам и «злостно интриговала» «с тщетной надеждой поднять свой пошатнувшийся престиж на Тихом океане» [156]. Британское влияние опиралось на эскадру в Тихом океане [117]. Также Англия рассчитывала на японские вооруженные силы.

Соперничество активизировалось после Японо-китайской войны. Отказ Японии от Ляодуна стал неприятной неожиданностью для Англии [33]. Заключение Китаем займа под гарантией России и соглашение о КВЖД стали «жестокими ударами для британского престижа». После занятия Порт-Артура русско-английские отношения вновь обострились; на этом этапе Япония и Англия не сходили с передовиц. Германская пресса, которую цитировали «Русские ведомости», уверяла, что Англия считала главным врагом именно Россию [26]. Исключительно против нее было направлено занятие Вәйхая [4]. (В противовес приводились и миролюбивые заверения английской печати: якобы Британия приобрела Вэйхай с целью защиты своих торговых интересов и сохранения равновесия [42]; акт не был направлен непосредственно против России [4].) В 1898 г. в Китай направилась миссия во главе с лордом Бересфордом, который старался расположить китайские власти к уступкам в пользу британской торговли и предостерегал их от русского влияния [33]. Англия старалась склонить к антирусской политике Германию, Японию и Соединенные Штаты [45]. Из документов «Синей книги» «Русские ведомости» делали вывод о том, что Британия придерживалась двойных стандартов: она выступала против политики разграничения «сфер влияния», когда речь шла о России, но отступала от этой позиции в отношении, к примеру, Германии. Как следствие политика лондонского кабинета «поминутно» вызывала осложнения в русско-английских отношениях на Дальнем Востоке - «хотя и не опасные, но тем не менее неприятные».

В апреле 1899 г. было заключено русско-английское соглашение о разделе районов железнодорожного строительства в Китае. Согласно отзыву «Times» это означало признание державами того, что Китай «достаточно велик для обеих» [37]. Однако и после этого Англия продолжила враждебные действия. Уже в начале боксерского восстания в «Русских ведомостях» появились сообщения о том, что Англию беспокоила возможная оккупация Россией северных провинций Китая. Британская пресса заявляла, что нельзя было безучастно отнестись к попытке России взять в свои руки подавление боксерского движения [30].

Позиция «Новостей» по отношению к Англии была более сложной: редакция также отмечала ее злонамеренность, однако настаивала на возможности общеевропейского согласия. В сентябре 1900 г. «Новости» манифестировали, что, хотя они не принадлежали «к числу отъявленных англофилов», было «еще далеко до того, чтобы видеть везде, кстати и некстати, одни лишь происки коварного Альбиона» [8]. При- 
знавалось, что интересы англичан в некоторой степени оправдывали их претензии: 80 процентов торговли в Китае приходилось на их долю [99]. Однако интересы отдельных стран должны были отступить перед общеевропейскими [77]. Державам следовало проявить солидарность в связи с азиатской угрозой: вопрос этот, «в сущности, сводится к борьбе цивилизации с невежеством, мрака со светом, права и справедливости с насилием и произволом».

Выбиваясь из общей европейской семьи, «коварный Альбион» [69] грешил чрезмерным эгоизмом. Редакция была возмущена тем, что Англия нашла предъявленные Японией условия Симоносекского договора отвечающими своим торговым интересам: «Иного отношения к делу нельзя было ожидать со стороны Англии, которая поставила выгоду краеугольным камнем своей политики» [71]. По поводу неприсоединения Лондона к тройственному вмешательству в руководящей статье было отмечено, что «никогда еще британский эгоизм не высказывался так резко и определенно, как в этой прискорбной истории» [72]. Заявление «Daily Mail», приветствовавшей Японию, поразило редакцию цинизмом, «Хотя с точки зрения английской политики, всегда отличавшейся эгоизмом и двоедушием», такие признания были «понятны и законны» [73]. Прогнозы относительно дальнейших действий англичан были пессимистичны: «Нынешние английские политики годятся лишь на то, чтобы кое-как следовать примеру своих предков. Поэтому более чем вероятно, что они и на Дальнем Востоке будут придерживаться своей излюбленной эгоистической политики» [75].

Как было отмечено в «Новостях», по случаю появления информации об уступке концессии на КВЖД английские газеты «с редким единодушием и с необыкновенной энергией дали понять японцам, что в случае войны с Россией они могут рассчитывать на помощь Великобритании» [78]. Английская печать стремилась восстановить против России и других европейцев, но не преуспела: «Великобритания всегда проповедовала столь исключительный культ своих эгоистических интересов, что теперь на ее крики мало обращают внимания». Германская пресса даже упрекнула ее в действиях «против коалиции европейских держав, восстающих во имя общеевропейских интересов...». Редакция укоризненно писала, что «высококультурная Англия, которой следовало бы, как передовой европейской державе, стоять во главе общеевропейско- го вмешательства, своим сепаратизмом явно нарушает общие интересы Европы».

Мнение это мог бы разделить и корреспондент «Новостей» в Пекине: он отмечал убежденность англичан в том, что «они должны пользоваться наибольшим влиянием на все дела; что на Востоке господствующий язык должен быть английский, что английские интересы должны подавлять все другие и пр.» [123]. В. Модестов отмечал, что Англия относилась к другим народам «слишком надменно», как к представителям низшей расы, живущим для увеличения благосостояния англичан [151]. Так оценив политику Англии, автор констатировал, что ее «колоссальное» могущество было еще далеко от заката: ведь речь шла о стране с «высокой культурой», средствами науки и опыта, знаниями, «несравненным политическим воспитанием» народных масс, «необыкновенным богатством». П. Кузнецов считал, что Англия в союзе с колониями «могла образовать такую коалицию против всего света, которая угрожает всем странам самыми печальными последствиями» [150]. Создав «федеративную империю», она грозила стать «страшной силой», которая «будет властвовать над миром». В то же время В. Верещагин утверждал, что власть англичан была хрупка [132]. При этом, как и коллеги, Верещагин отмечал «крайнюю неразборчивость в средствах для обогащения своих за счет чужих», «изумительную жестокость» и заключал: «...англичане в отдельности милые, прекрасные люди, настоящие джентльмены, с которыми приятно иметь сношения, но со всей английской нацией если и лучше жить в мире, чем ссориться, то, во всяком случае, необходимо всегда держать камень за пазухой». Именно этим принципом, вероятно, и диктовалось отношение редакции «Новостей» к Англии.

Помимо предательства общеевропейских интересов отмечалась и враждебность Англии непосредственно по отношению к России. «Всюду, во всех предприятиях русского правительства, Англия становилась ему поперек пути, всюду совалась со своими вездесущими интересами, всегда и везде проявляла ожесточенную ненависть к России» [98]. По случаю тройственного вмешательства английские газеты «очень бы хотели втянуть Россию в новую войну» [73]. Было отмечено, что неудачи «в Англии давно уже привыкли вымещать все на России» (все же следовало относиться к Англии терпимо, поскольку «серьезная ссора» стала бы «великим бедствием, которого следует всячески избегать» [79]). 


\section{Исторический журнал: научные исследования № 6 (24) 2014}

DOI: 10.7256/2222-1972.2014.6.14860

Англия была опасна не столько в военном отношении (она могла прибегнуть к прямой агрессии, только если бы державы посягнули на ее торговлю с Китаем [95]), сколько по части интриг: Британия стремилась извлекать пользу из конфликтов между державами [91]. После вступления русских в Порт-Артур Лондон настраивал против России Японию, побуждал китайского императора к перенесению резиденции в Нанкин [87], пытался создать тройственный союз Англии, Японии и Соединенных Штатов [90]. Известие об аренде Порт-Артура было «повсюду встречено с сочувствием, за исключением Англии» [92]. Вся Европа осознала, что этот шаг был, безусловно, необходим; по мнению «Fremdenblatt», Россия «оказывала услугу европейскому миру». При этом Англия «сделала бы со своей стороны все возможное, чтобы помешать России, но, к счастью, очутилась изолированной». Лондон вел себя несознательно: что ж, «не вина России, если страна, мнящая себя самой культурной страной, ставит тормозы ее великим культурным начинаниям» [116].

«В интересах мира» «Новости» в 1897 г. предлагали сменить «нежелательный и вредный» [88] антагонизм согласием. Так, по поводу сведений о стремлении Англии к оккупации Вэйхая редакция (отметив, что Англия «явно нарушила равновесие») выражала надежду на то, что «обе державы сумеют сохранить дружеские отношения и совокупными силами будут способствовать водворению европейской цивилизации на Востоке» [94]. Интересы Англии и России не входили в противоречие [79]. Говоря об англорусском антагонизме, редакция «Новостей» уверяла в необходимости «покончить с этим вредным предрассудком, мешающим установлению между Англией и Россией таких же дружеских и искренних отношений, какие ныне связывают между собою Россию и Францию». Владения стран-соперниц были и без того «так огромны, что расширять их еще более представляется неудобным и даже опасным». России незачем было вызывать Англию «на борьбу» [92]. Следовало найти баланс, при котором возможным стало бы мирное удовлетворение «законных интересов» держав [93]. Редакция «Новостей» «всегда старалась поддерживать идею англо-русского соглашения», считая, что «обеим державам хватит места в Азии» [97]. Россия «никогда не отказывалась от искреннего и совместного действия с Англией, - писала редакция о будущей экспедиции в Китай. - Но прежде всего необходимо, чтобы
Англия отрешилась от своей отталкивающей политики заподазриваний и окриков относительно России» [100]. Впрочем, Англия не была всецело недоброжелательна: само правительство было «далеко от шовинистических увлечений», а местные либеральные газеты были «совершенно согласны» с идеей «Новостей», по которой «задачей обеих держав должно поставить устранение недоразумений и искусственно возбуждаемого и вредного антагонизма» [93]. Соглашение было «возможно и желательно» - при условии «полной равноправности и добросовестности» (допускалось, что Англия будет пользоваться услугами России в одностороннем порядке и не станет признавать русские военные подвиги в Китае) [102].

В июле 1900 г., в разгар подавления восстания ихэтуаней, «Новости» привели версию «Гражданина», согласно которой Англия стремилась разжечь пожар, чтобы уничтожить престиж России в Китае; автор обзора прессы комментировал: Лондону нельзя было «предоставить распоряжаться в Китае» [70]. (Однако, хотя и будучи «не особенно высокого мнения о политических приемах Англии» и допуская «возможность разных диверсий с ее стороны», «Новости» «решительно утверждали, что "в китайском кризисе Англия неповинна”»: поскольку для нее он не был выгоден [103].)

В 1900 г. Е. Оболенский говорил о «необходимости идти до конца путем общего соглашения как единственного средства от мрачных последствий еще небывалой по размерам всемирной войны» [153]. Ни Англия, ни Россия не нуждались в территориальных приобретениях, им следовало «остаться при status quo и совокупными силами заботиться об охране интересов собственных подданных» [101]. Редакция вновь писала, что «взгляд на Англию и Россию как на исконных и непримиримых врагов <..> есть опасное и нелепое заблуждение, которое поддерживается больше в Англии, чем в России». В августе 1900 г. М. Энгельгардт писал даже, что «если есть союз, выгодный для обеих сторон, то именно союз Англии с Россией» [159]. Ввиду опасности Германии, Японии и США, «потенциальная энергия захвата которых совсем еще не использована», следовало прекратить «ненужные раздоры».

«Судорожные попытки» англичан протестовать против занятия русскими войсками Маньчжурии вызывали у редакции «более жалости, чем негодования» [107]. В декабре 1901 г. 
«Новости» признавали, что англо-русский союз был «совершенно бесполезной утопией» [108]. Однако «весьма ненормальные» отношения должны были стать хотя бы «более доверчивыми и более нормальными». Россия «постоянно была жертвой английской подозрительной и завистливой политики». Британская печать соблюдала «традиции систематической вражды и неприязни к России». «С прискорбием указывая на это печальное обстоятельство», «Новости» утверждали, что улучшение русско-английских отношений было возможно в случае изменения английской политики. Только когда «в Англии выучатся смотреть на Россию без предубеждения и без подозрительности, как прилично великому культурному народу», а в России «перестанут относиться к Англии только как к мучительнице буров», можно будет говорить и о политическом сближении.

В обзоре 1901 г. «Новости» доводили до сведения читателя, что англо-русские отношения «не только были вполне удовлетворительны, но еще более улучшились и стали еще более дружественными» [7]. Английская печать обнаружила «решительное стремление к сближению с Россией». 31 января 1902 г. (на следующий день после подписания англо-японского союзного договора) сообщалось, что Англия переходит к более дружественным отношениям с Россией; выражалась надежда на то, что «двадцатое столетие будет счастливее девятнадцатого и увидит Россию и Англию в состоянии взаимного доверия, которое должно заменить прежний антагонизм» [109].

На заключение договора «Новости» отреагировали сдержанно, заявив, что соглашение было «новым актом миролюбия» и имело «второстепенное значение»: союзники, как и Россия, стремились поддержать независимость Китая и Кореи [110]. К вопросу о Маньчжурии соглашение отношения не имело [111]. (Несмотря на видимую сдержанность в отношении к «второстепенному» соглашению, в газете появилась особая колонка «Англо-японский союз».) Несколько язвительно «Новости» констатировали, что в Англии восторги «уступили место известному разочарованию» [112]. Англичане были «неприятно поражены отношением русской печати к этому договору. Там ожидали сердитых бранных отзывов, а встретили совсем иное. Русская печать в самом спокойном и благожелательном тоне оценила англо-японский договор и тем поставила английских публицистов в неловкое, почти комическое положение».
«Курьер» также отзывался о британской политике критически и также убеждал в необходимости мирных конструктивных взаимоотношений (в отличие от «Новостей» отмечая антагонизм интересов).

Подобно многим коллегам, анонимный политический обозреватель «Курьера» считал, что англичане «смотрели на восточные народы как на объект коммерческой эксплуатации» [55] и никогда не руководствовались благом государств, в защиту которых выступали [57]. Англия «меньше всего» думала об интересах Китая и желала бы, «чтобы другие державы там интересов не имели». На первый план Лондон ставил личные интересы и «меньше всего» руководствовался принципами [56]. Англия слыла «единственной нарушительницей всеобщего мира, к которому стремится Европа» [5]. Лондон пытался противодействовать русской политике, в качестве инструмента рассматривая альянсы для создания противовеса России, но другие державы не намеревались «таскать каштаны из огня» [34]. Несомненно было, что Англия все больше убеждалась в том, что «только при согласии России с Англией можно предотвратить тот мировой пожар, который может повлечь за собой раздел Китая». Впрочем, при всем желании установить дружественные отношения противоположность интересов была настолько разительна, что при любом раскладе оставалась «почва для недоразумений, и более всего по вине Англии, которая никак не может примириться с влиятельным положением, занятым Россией на Востоке» [61]. В 1899 г. редакция «Курьера» «приветствовала» речь Р. Солсбери об англо-русском соглашении, предметом которого стало разграничение сфер влияния [62]. Премьер-министр считал «желательным» усиление «доброго расположения» между Англией и Россией. «Курьер» также цитировал публикацию газеты «Manchester Guardian», отличавшейся «большой вдумчивостью статей»: сам факт соглашения был отраден, поскольку оно устраняло «повод к распрям» и должно было положить конец опасной, «недостойной и напрасной борьбе из-за концессий» [63].

Однако согласия не наступало. «Курьер» отмечал, что «англичане ревниво следят за каждым успехом России в Китае» [24]. Редакция «Курьера» отмечала в мае 1900 г. «резкие нападки» английской печати [66]. Газеты публиковали антироссийские статьи, чтобы «подхлестывать» общественное мнение [122]. В июньском обзоре 


\section{Исторический журнал: научные исследования № 6 (24) • 2014}

DOI: $10.7256 / 2222-1972.2014 .6 .14860$

прессы в 1900 г. цитировались «Московские ведомости», согласно которым англичане делали все, чтобы втянуть Россию в войну с Японией или Китаем до окончания постройки Транссибирской магистрали [38]. (Было представлено и иное мнение: Л. А. Богданович утверждал, что Англия была слишком слаба из-за войны с бурами, чтобы стремиться к военному конфликту в Китае [128]. Аналитик писал, что часть русской печати, обвинявшая британское правительство в организации восстания, «жестоко ошибалась»: «Англия слишком сильно заинтересована материально в Китае, слишком много ее подданных подвергается там жестокой опасности...» [114].)

В июне 1900 г. «Курьер» упоминал «старинную неприязнь Англии к России» [113]. Британские газеты публиковали статьи, направленные против России, чтобы «подхлестывать» общественное мнение [123]. Лондонский корреспондент также сообщал об антироссийских настроениях прессы; общество же «чуть не со школьной скамьи привыкло смотреть на Россию как на своего рода Китай, а на русских - как на варваров» [118]. Корреспондент уверял, что между Россией и Англией «слишком большая разница, чтобы можно было серьезно говорить о единстве их целей и стремлений». На англояпонское соглашение «Курьер» отреагировал достаточно сухо. Текст появился среди телеграмм, после сообщений о признании Батуми благополучным от чумы и о землетрясении в Баку [154]. К нему прилагались официальные объяснения английской и японской сторон, согласно которым соглашение имело мирный характер. В следующем номере в «Телеграммах» также приводились успокоительные заверения англичан [155]. Кроме того, цитировались слова парижского «Correspondance Diplomatique» о том, что по существу договор ничего не менял. Упоминалось также мнение английского «Economist», согласно которому союз был «во многих отношениях выгоден для Англии, но цена, которой куплены эти выгоды, слишком высока. Да и значение этих выгод не следует преувеличивать» [25]. Аналитик присутствовал в статье за авторством «Политика» [121]. Тот упоминал, что в основе «погони за союзами» были «хищнические стремления»; наказав китайцев, европейцы занялись удовлетворением «ненасытного аппетита». Предполагалось, что ввиду недавнего сближения США и Германии России нечего было «опасаться последствий англо-японского соглашения»: открывалась возможность выбрать «ту группу, которая наиболее соответствует нашим интересам на Дальнем Востоке».

«Русская мысль» также упоминала желательность согласия с Англией, при этом осуждая британский эгоизм: В. А. Гольцев предостерегал Россию от «своекорыстной и хищнической политики Англии», «которую многие из наших самобытников предлагают за образец для России», поскольку политика эта вела к пагубным последствиям [133, 243-250]. В 1896 г. международный обозреватель допускал возможность объединения России, Франции и Англии; конечно, «во многих случаях» задачи Англии не соответствовали русской и французской международной политике [20, 218]. Англия «многократно - то открыто, то тайно - выступала против законных интересов России»; ее «не совсем напрасно прозвали коварным Альбионом, и надо зорко следить за ее действиями».

Впрочем, бывало, что и Россия противодействовала «не менее законным интересам Великобритании». Это не отменяло возможности согласовать интересы и создать группировку, которая предоставила бы союзникам «преобладающее значение в мире». В контексте вопроса о геноциде армян Гольцев считал соглашение с «коварным Альбионом» «и возможным, и весьма желательным, конечно, при предположении, что русская дипломатия оградит наши национальные интересы» [21, 238].

В апреле 1898 г. Гольцев утверждал, что «Русская мысль» «давно и почти одиноко выступала в русской печати в пользу дружественного соглашения с Англией в вопросах азиатской политики» [137, 193], указывая на вред культа ненависти к «коварному Альбиону» [136, 178]. Безосновательная вражда могла предоставить выгоду только третьей стороне, но никак не конфликтующим [140, 185]; соперничество могло быть «пагубно для европейской цивилизации и европейского влияния в Азии» $[134,221]$. Напротив, англофранко-русское соглашение изменило бы международные отношения к лучшему [138, 233]. Обеим соперницам предстояло решение множества «великих, в высшей степени трудных культурных задач» в Азии [139, 172]. Увы, Лондон не был готов к сближению: так, по замечанию Гольцева, во время похода на Пекин союзники действовали дружно, и только «Англия играла довольно двусмысленную роль и послала к Пекину лишь незначительный отряд войск» [143, 242].

В «Вестнике Европы», как и в других изданиях, отмечалась необходимость выстраивать 
мирные взаимоотношения, невзирая на агрессивность британской политики. В 1900 г. международный обозреватель предостерегал: несмотря на военно-политический кризис Англии, не стоило недооценивать ее военные силы [14, 582]. Отношения России с англичанами, «как и с другими великими нациями», должны были быть рассчитаны на долговременную перспективу. Прочный мир был бы невозможен, «если бы каждое государство пользовалось затруднениями другого для корыстных набегов или двусмысленных комбинаций».

В июле 1900 г. «Вестник Европы» признавал стремление Англии противопоставить России Японию [15, 370-375]. При этом он осуждал русских, которые «громили Англию с необыкновенным усердием и доказывали весьма настойчиво, что для нас будто бы гораздо важнее сохранить прочную дружбу с Китаем, чем с Англией и вообще с Европой». Раздоры были неуместны: и англичане, и русские «газетные патриоты» забывали, что речь шла о безопасности европейцев. Замечалось, что, хотя русские газеты усвоили «сильнейший воинственный тон» в отношении Англии, в последней распространялось «убеждение в необходимости прочного мира и согласия с Россией». Следовало относиться к владычице морей миролюбиво «и идти навстречу возможным с ней соглашениям, чтобы избегнуть в будущем опасных конфликтов с британским флотом».

В 1900 г. отмечалось, что «постоянные старания сеять раздор между державами придают лондонской печати какой-то злобный, интриганский оттенок» $[16,352]$. Упоминалась «всегдашняя бесцеремонность Англии во внешних делах». Она пребывала «в постоянном антагонизме с Россией в области восточных, и в частности китайских, дел...» $[17,803]$. В 1901 г. по поводу маньчжурского вопроса в «Вестнике Европы» информировали, что ситуация грозила «серьезно испортить отношение к нам Англии, которая, впрочем, никогда не отличалась особой дружественностью» $[18,829]$.

Англо-японский союзный договор «Вестник Европы» не воспринял в качестве серьезной угрозы. Англия брала на себя «щекотливые и тягостные обязательства», и автор обозрения не постигал, для чего ей понадобилось вступать в такой союз [19, 369-370].

В «Русском богатстве» отмечались и опасность Англии, и необходимость найти с ней общий язык. С. Н. Южаков считал приоритетны- ми общемировые интересы: обобщая события 1897 г., он сетовал, что международная жизнь «мало подвинула дело цивилизации, более вращаясь в сфере узких национальных интересов» [163, 131]. Аналитик не одобрял англо-русских конфликтов в Китае, выражая надежду на то, что европейцы «найдут достойный исход этих печальных пререканий» [163, 235]. Надежды было мало: в 1899 г. Южаков опасался, что Британия могла в одиночку «рискнуть на войну даже с коалицией» $[168,112]$. У нее были и союзники, в том числе США и Япония. Также отмечалось «явное сближение с Германией, хотя, конечно, это не сателлит». В обзоре событий 1900 г. Южаков предупреждал об опасности англосаксов [170, 204-206]. Их преобладание могло смениться господством: «Этот белый призрак англосаксонского господства гораздо реальнее желтого призрака монгольского нашествия. <...> Он опасен национальной свободе народов и их народному благосостоянию». Все же международный обозреватель не вполне осуждал Британию: ее значение не исчерпывалось «победным шествием империализма» [171, 125-127]. Англия представляла собой «хранительницу таких твердых и светлых традиций истинно европейской культуры, что умаление ее значения и влияния должно неблагоприятно отразиться в общем ходе европейской истории».

Приводя в феврале 1902 г. ряд политических событий, «наиболее волновавших цивилизованный мир», прежде всего Южаков упомянул (в негативном ключе) англо-японский союз [169, 121-131]. Отчуждение Европы изза «бесславной южноафриканской политики» заставило Лондон «искать друзей, кто бы они ни были», что привело к союзу с Японией. Англичане «жаждали друга. И друг явился, хотя и цветнокожий (для англосаксов это очень много значит), хотя и как будто варвар... Однако всетаки друг». Автор не был склонен недооценивать значение этого союза. Мирные отношения Англии с «цивилизованными странами» ставились в зависимость от «варварской» Японии; Великобритания «получила серьезную опору империалистской политике». Характерно, что значение союза автор предпочел выяснить, сравнив морские и сухопутные силы на Дальнем Востоке. Поддержка со стороны моря делала армию Японии «очень серьезной наступательной силой».

Признавая агрессивность и враждебность Англии, «Неделя» отзывалась о стране с уваже- 


\section{Исторический журнал: научные исследования № 6 (24) • 2014}

DOI: 10.7256/2222-1972.2014.6.14860

нием. В статье к юбилею королевы Виктории было сказано немало почтительных слов [3]. Над империей веял «дух закономерной свободы и уважения к человеческому достоинству». Правда, были и «мрачные пятна» на истории царствования - Ирландия и Индия, - но англичане знали об этих «роковых ошибках» и делали «благородные усилия изгладить их». «Великий народ, духовная сила которого столь ощутительно влияет на человеческий прогресс», достиг «величайшего могущества» и «наибольшей просвещенности и благоустроенности». С. Рапапорт, автор писем из Лондона, утверждал, что «за Англией давно утвердилась репутация не только “коварного", но и гордого Альбиона, - страны, идущей во главе цивилизованных стран $<\ldots>$ и политическая свобода в ней более упрочена, материальное богатство более заметно, и порядка в ней вообще больше, чем где бы то ни было в Европе. Этого не могут отрицать даже враги ее» [153]. Англию характеризовали «сильный флот, развитая промышленность, грамотное и здоровое население, целесообразное и гуманное законодательство».

В 1898 г. «Неделя» отмечала, что «к России англичане продолжали относиться враждебно» [48]. В 1898 г. в статье «специалиста-моряка» говорилось, что отпущенные для строительства новых кораблей деньги следовало истратить исходя из наиболее вероятного противника: «Опаснейшим для нас противником на море всегда была, есть и еще будет десятки лет - Англия (впрочем, последние события заставили обратить внимание на Японию)» [1]. В 1901 г. в политической рубрике предупреждали об опасности экспансии англосаксов: «Со времени китайских событий много толковали о “желтой опасности”, о порабощении Китаем-варваром культурной Европы, но “белый призрак” англосаксонского господства над миром, пожалуй, будет реальнее монгольского нашествия» [49].

В декабре 1901 г. журнал «Новое дело» информировал, что в Англии, «по-видимому, зреет течение, благоприятное России» [50]. Об этом говорил ряд статей в пользу союза с Россией за авторством «видных представителей английского политического мира». Англо-японский союз был заключен «при сравнительно полном политическом затишье и среди отвлеченных разговоров и предположений о новых дипломатических комбинациях держав» [51]. Договор этот был «величайшей политической важности». Судя по нему, «политическое значение Англии сильно пошатнулось». Японии договор был выгоден: она обезопасила себя от «серьезного соперника в лице России». Признавалось, что «союз носит безусловно агрессивный характер, цели его ясны, а также понятно, против каких держав он направлен».

Таким образом, несмотря на достаточно широкий спектр мнений, выраженных на страницах столичной либеральной прессы, в освещении политики ключевых западных участников «китайского вопроса» существовали определенные тенденции. Во многом они отражали взгляды представителей образованных слоев русского общества, которых те придерживались относительно будущего Китая. Условно говоря, международная политика великих держав оценивалась по двум выраженным шкалам. «Русские ведомости» выделяли два центра притяжения - Россию и Англию (из «нейтральных» стран ближе к России была Германия, ближе к Англии - США). Действия других стран во многом оценивались в зависимости от близости к одному из этих полюсов. Другой оценочный принцип достаточно четко прослеживался в публикациях «Новостей»: положительно оценивались просвещенные страны Запада, отрицательно - варварские страны Востока.

В целом можно заключить, что либеральная пресса приветствовала союзную Францию. Отношение к Германии и США было сложнее. Оба государства были достаточно агрессивными, представляли собой сильных конкурентов и являлись объектами антироссийских интриг Англии; Германия и сама была не прочь поучаствовать в интригах. Несмотря на пересечение интересов, державам следовало оставить разногласия в интересах мира и общеевропейской солидарности.

Отношение прессы к Англии было в разной мере негативным. Многократно отмечались опасный эгоизм англичан, их интриги и постоянное противодействие России. Однако даже в «Русских ведомостях», сотрудники которых отзывались о Британии с особой резкостью, не раз указывалось на необходимость если не союза, то мирного сосуществования на Дальнем Востоке. В интересах мира России следовало достичь согласия с Англией. Препятствием служила только несознательная политика Лондона, который продолжал противодействие во многом вопреки собственным интересам. 


\section{Библиография:}

1. [Ад.] Какие суда строить? // Неделя. 1898. № 16.

2. [Анонимный автор] $1877=$ двадцатипятилетние «Новостей» $=1902$ // Новости. 1902. № 1.

3. [Анонимный автор] Английское торжество // Неделя. 1897. № 24.

4. [Анонимный автор] Англия и Россия на Дальнем Востоке // Русские ведомости. 1898. № 88.

5. [Анонимный автор] Великие проблемы // Курьер. 1900. № 86.

6. [Анонимный автор] Внешняя политика России // Новости. 1900. № 1.

7. [Анонимный автор] Внешняя политика России в 1901 году // Новости. 1902. № 1.

8. [Анонимный автор] Военные действия в Китае // Новости. 1900. № 255.

9. [Анонимный автор] Иностранное обозрение // Вестник Европы. 1895. Т. 4. Кн. 7. С. 361-362.

10. [Анонимный автор] Иностранное обозрение // Вестник Европы. 1896. Т. 1. Кн. 1. С. 397.

11. [Анонимный автор] Иностранное обозрение // Вестник Европы. 1898. Т. 1. Кн. 1. С. 398-400.

12. [Анонимный автор] Иностранное обозрение // Вестник Европы. 1898. Т. 5. Кн. 9. С. 380-383.

13. [Анонимный автор] Иностранное обозрение // Вестник Европы. 1898. Т. 7. Кн. 12. С. 786.

14. [Анонимный автор] Иностранное обозрение // Вестник Европы. 1900. Т. 1. Кн. 1. С. 382-383.

15. [Анонимный автор] Иностранное обозрение // Вестник Европы. 1900. Т. 4. Кн. 7. С. 365-375.

16. [Анонимный автор] Иностранное обозрение // Вестник Европы. 1900. Т. 5. Кн. 9. С. 346-358.

17. [Анонимный автор] Иностранное обозрение // Вестник Европы. 1900. Т. 7. Кн. 12. С. 802-807.

18. [Анонимный автор] Иностранное обозрение // Вестник Европы. 1901. Т. 2. Кн. 4. С. 823-829.

19. [Анонимный автор] Иностранное обозрение // Вестник Европы. 1902. Т. 1. Кн. 1. С. 378-379.

20. [Анонимный автор] Иностранное обозрение // Русская мысль. 1896. Кн. 10. С. 218.

21. [Анонимный автор] Иностранное обозрение // Русская мысль. 1896. Кн. 11. С. 238.

22. [Анонимный автор] Иностранное обозрение // Русские ведомости. 1896. № 1.

23. [Анонимный автор] Иностранное обозрение // Русские ведомости. 1898. № 1.

24. [Анонимный автор] Иностранные известия // Курьер. 1900. № 121.

25. [Анонимный автор] Иностранные известия // Курьер. 1902. № 43.

26. [Анонимный автор] Иностранные известия // Русские ведомости. 1898. № 87.

27. [Анонимный автор] Иностранные известия // Русские ведомости. 1898. № 253.

28. [Анонимный автор] Иностранные известия // Русские ведомости. 1898. № 276.

29. [Анонимный автор] Иностранные известия // Русские ведомости. 1899. № 307.

30. [Анонимный автор] Иностранные известия // Русские ведомости. 1900. № 148.

31. [Анонимный автор] Иностранные известия // Русские ведомости. 1900. № 173.

32. [Анонимный автор] Иностранные известия // Русские ведомости. 1902. № 30.

33. [Анонимный автор] Китай и европейские державы. Китай и Англия // Русские ведомости. 1900. № 230.

34. [Анонимный автор] Материал без заголовка // Курьер. 1899. № 68.

35. [Анонимный автор] Материал без заголовка // Курьер. 1900. № 149.

36. [Анонимный автор] Материал без заголовка // Новости. 1900. № 298.

37. [Анонимный автор] Материал без заголовка // Русские ведомости. 1899. № 112.

38. [Анонимный автор] 0 чем пишут // Курьер. 1900. № 160.

39. [Анонимный автор] О чем пишут // Курьер. 1900. № 172.

40. [Анонимный автор] Передовая статья // Курьер. 1897. № 31.

41. [Анонимный автор] Передовая статья // Русские ведомости. 1898. № 65.

42. [Анонимный автор] Передовая статья // Русские ведомости. 1898. № 85.

43. [Анонимный автор] Передовая статья // Русские ведомости. 1898. № 150.

44. [Анонимный автор] Передовая статья // Русские ведомости. 1898. № 223.

45. [Анонимный автор] Передовая статья // Русские ведомости. 1899. № 70.

46. [Анонимный автор] Передовая статья // Русские ведомости. 1900. № 159.

47. [Анонимный автор] Политические известия // Неделя. 1895. № 17.

48. [Анонимный автор] Политические известия // Неделя. 1898. № 14.

49. [Анонимный автор] Политические известия // Неделя. 1901. № 1.

50. [Анонимный автор] Политические известия // Новое дело. 1901. № 2. С. 41.

51. [Анонимный автор] Политические известия // Новое дело. 1902. № 6. С. 168-169.

52. [Анонимный автор] Политическое обозрение // Курьер. 1897. № 31.

53. [Анонимный автор] Политическое обозрение // Курьер. 1898. № 5.

54. [Анонимный автор] Политическое обозрение // Курьер. 1898. № 86.

55. [Анонимный автор] Политическое обозрение // Курьер. 1898. № 93.

56. [Анонимный автор] Политическое обозрение // Курьер. 1898. № 102.

57. [Анонимный автор] Политическое обозрение // Курьер. 1898. № 129.

58. [Анонимный автор] Политическое обозрение // Курьер. 1898. № 206. 


\title{
Исторический журнал: научные исследования № 6 (24) • 2014
}

\author{
DOI: $10.7256 / 2222-1972.2014 .6 .14860$
}

59. [Анонимный автор] Политическое обозрение // Курьер. 1898. № 215.

60. [Анонимный автор] Политическое обозрение // Курьер. 1898. № 335.

61. [Анонимный автор] Политическое обозрение // Курьер. 1899. № 59.

62. [Анонимный автор] Политическое обозрение // Курьер. 1899. № 110.

63. [Анонимный автор] Политическое обозрение // Курьер. 1899. № 113.

64. [Анонимный автор] Политическое обозрение // Курьер. 1900. № 59.

65. [Анонимный автор] Политическое обозрение // Курьер. 1900. № 64.

66. [Анонимный автор] Политическое обозрение // Курьер. 1900. № 147.

67. [Анонимный автор] Положение дел в Китае // Русские ведомости. 1898. № 118.

68. [Анонимный автор] Положение дел на крайнем Востоке // Русские ведомости. 1899. № 301.

69. [Анонимный автор] Русская печать // Новости. 1895. № 161.

70. [Анонимный автор] Русская печать // Новости. 1900. № 154.

71. [Анонимный автор] Санкт-Петербург // Новости. 1895. № 94.

72. [Анонимный автор] Санкт-Петербург // Новости. 1895. № 101.

73. [Анонимный автор] Санкт-Петербург // Новости. 1895. № 102.

74. [Анонимный автор] Санкт-Петербург // Новости. 1895. № 121.

75. [Анонимный автор] Санкт-Петербург // Новости. 1895. № 257.

76. [Анонимный автор] Санкт-Петербург // Новости. 1895. № 274.

77. [Анонимный автор] Санкт-Петербург // Новости. 1895. № 286.

78. [Анонимный автор] Санкт-Петербург // Новости. 1895. № 289.

79. [Анонимный автор] Санкт-Петербург // Новости. 1895. № 299.

80. [Анонимный автор] Санкт-Петербург // Новости. 1895. № 357.

81. [Анонимный автор] Санкт-Петербург // Новости. 1896. № 235.

82. [Анонимный автор] Санкт-Петербург // Новости. 1897. № 219.

83. [Анонимный автор] Санкт-Петербург // Новости. 1897. № 288.

84. [Анонимный автор] Санкт-Петербург // Новости. 1897. № 309.

85. [Анонимный автор] Санкт-Петербург // Новости. 1897. № 310.

86. [Анонимный автор] Санкт-Петербург // Новости. 1897. № 331.

87. [Анонимный автор] Санкт-Петербург // Новости. 1897. № 342.

88. [Анонимный автор] Санкт-Петербург // Новости. 1897. № 344.

89. [Анонимный автор] Санкт-Петербург // Новости. 1897. № 345.

90. [Анонимный автор] Санкт-Петербург // Новости. 1897. № 356.

91. [Анонимный автор] Санкт-Петербург // Новости. 1898. № 4.

92. [Анонимный автор] Санкт-Петербург // Новости. 1898. № 79.

93. [Анонимный автор] Санкт-Петербург // Новости. 1898. № 82.

94. [Анонимный автор] Санкт-Петербург // Новости. 1898. № 85.

95. [Анонимный автор] Санкт-Петербург // Новости. 1898. № 17.

96. [Анонимный автор] Санкт-Петербург // Новости. 1899. № 298.

97. [Анонимный автор] Санкт-Петербург // Новости. 1899. № 30.

98. [Анонимный автор] Санкт-Петербург // Новости. 1899. № 359.

99. [Анонимный автор] Санкт-Петербург // Новости. 1900. № 31.

100. [Анонимный автор] Санкт-Петербург // Новости. 1900. № 149.

101. [Анонимный автор] Санкт-Петербург // Новости. 1900. № 155.

102. [Анонимный автор] Санкт-Петербург // Новости. 1900. № 166.

103. [Анонимный автор] Санкт-Петербург // Новости. 1900. № 197.

104. [Анонимный автор] Санкт-Петербург // Новости. 1900. № 291.

105. [Анонимный автор] Санкт-Петербург // Новости. 1900. № 311.

106. [Анонимный автор] Санкт-Петербург // Новости. 1901. № 32.

107. [Анонимный автор] Санкт-Петербург // Новости. 1901. № 204.

108. [Анонимный автор] Санкт-Петербург // Новости. 1901. № 350.

109. [Анонимный автор] Санкт-Петербург // Новости. 1902. № 31.

110. [Анонимный автор] Санкт-Петербург // Новости. 1902. № 33.

111. [Анонимный автор] Санкт-Петербург // Новости. 1902. № 38.

112. [Анонимный автор] Санкт-Петербург // Новости. 1902. № 43.

113. [Анонимный автор] События в Китае // Курьер. 1900. № 168.

114. [Анонимный автор] События в Китае // Курьер. 1900. № 171.

115. [Анонимный автор] Черные точки // Неделя. 1895. № 29.

116. [Анонимный автор] Шах и мат // Новости. 1898. № 85.

117. [Анонимный автор] Эскадры держав на Дальнем Востоке // Русские ведомости. 1898. № 78.

118. [Анонимный корреспондент] Новый тройственный союз // Курьер. 1900. № 175. 
119. [Анонимный корреспондент] Телеграфические известия. Берлин (от нашего корреспондента) // Русские ведомости. 1901. № 62.

120. [П. К.] Борьба русской и американской промышленности на азиатских рынках в 1897 г. // Курьер. 1898. № 272.

121. [Политик] Сближение между Германией и Соединенными Штатами // Курьер. 1902. № 49.

122. [Странник] Подхлестыватели общественного мнения // Курьер. 1900. № 155.

123. [Тек] Письма из Пекина // Новости. 1897. № 58.

124. [Тек] Письма с Дальнего Востока // Новости. 1897. № 357.

125. [Х.] По поводу событий в Китае // Курьер. 1900. № 174.

126. [Z.] Лондон (от нашего корреспондента) // Новости. 1895. № 109.

127. Анучин Д. Н. Китай и европейские державы // Русские ведомости. 1900. № 248.

128. Богданович Л. А. На крайнем Востоке // Курьер. 1900. № 168.

129. Богданович Л. А. Правда о революции на Филиппинах // Курьер. 1900 . № 93.

130. Василевский И. Ф. Петербургские наброски (Что пишут теперь в Европе по поводу Англии?) // Русские ведомости. 1899. № 343.

131. Верещагин В. Листки из записной книжки // Новости. 1900. № 245.

132. Верещагин В. Могущественна ли Англия? // Новости. 1896. № 15.

133. Гольцев В. А. 1895 год в политическом отношении // Русская мысль. 1896. Кн. 1. С. 243-250.

134. Гольцев В. А. 1899 год в политическом отношении // Русская мысль. 1900. Кн. 1. С. 221-226.

135. Гольцев В. А. 1900 год в политическом отношении // Русская мысль. 1901. Кн. 1. С. 208-214.

136. Гольцев В. А. Иностранное обозрение // Русская мысль. 1898. Кн. 4. С. 178-179.

137. Гольцев В. А. Иностранное обозрение // Русская мысль. 1898. Кн. 6. С. 193.

138. Гольцев В. А. Иностранное обозрение // Русская мысль. 1898. Кн. 9. С. 233.

139. Гольцев В. А. Иностранное обозрение // Русская мысль. 1899. Кн. 2. С. 172.

140. Гольцев В. А. Иностранное обозрение // Русская мысль. 1899. Кн. 5. С. 185.

141. Гольцев В. А. Иностранное обозрение // Русская мысль. 1899. Кн. 6. С. 225.

142. Гольцев В. А. Иностранное обозрение // Русская мысль. 1900. Кн. 6. С. 211-212.

143. Гольцев В. А. Иностранное обозрение // Русская мысль. 1900. Кн. 8. С. 242.

144. Гольцев В. А. Иностранное обозрение // Русская мысль. 1900. Кн. 11. С. 273-274.

145. Гольцев В. А. Иностранное обозрение // Русская мысль. 1901. Кн. 2. С. 201-202.

146. Гольцев В. А. Иностранное обозрение // Русская мысль. 1902. Кн. 3. С. 222-223.

147. Гольцев В. А. Мысли вслух // Курьер. 1900. № 183.

148. Иоллос Г. Б. Иностранные известия. Берлин // Русские ведомости. 1898. № 33.

149. Корсаков В. В. Европейские школы в Китае // Русские ведомости. 1898. № 138.

150. Кузнецов П. Британский империализм // Новости. 1897. № 206.

151. Модестов В. Могущество Англии // Новости. 1896. № 14.

152. Оболенский Е. Мировые интересы в Китае // Новости. 1900. № 161.

153. Рапапорт С. Рабочая Англия // Неделя. 1897. № 32.

154. Телеграммы // Курьер. 1902. № 32.

155. Телеграммы // Курьер. 1902. № 33.

156. Телеграфические известия // Русские ведомости. 1895. № 288.

157. Телеграфические известия // Русские ведомости. 1901. № 148.

158. Телеграфические известия // Русские ведомости. 1902. № 50.

159. Энгельгардт М. Россия и Англия против Германии // Новости. 1900. № 226.

160. Энгельгардт М. Старые соперники и новые претенденты // Новости. 1900. № 233.

161. Южаков С. Н. Дневник журналиста // Русское богатство. 1897. Кн. 8. С. 106-131.

162. Южаков С. Н. Политика // Русское богатство. 1898. Кн. 2. С. 107-131.

163. Южаков С. Н. Политика // Русское богатство. 1898. Кн. 8. С. 233-235.

164. Южаков С. Н. Политика // Русское богатство. 1900. Кн. 11. С. 155-156.

165. Южаков С. Н. Политика // Русское богатство. 1901. Кн. 5. С. 144-153.

166. Южаков С. Н. Политика // Русское богатство. 1902. Кн. 2. С. 121-132.

167. Южаков С. Н. Политика. 1898 год // Русское богатство. 1899. Кн. 1. С. 101-117.

168. Южаков С. Н. Политика. Год 1900 // Русское богатство. 1900. Кн. 12. С. 204-206.

169. Южаков С. Н. Политика. Первый год молодого века // Русское богатство. 1901. Кн. 12. С. 118-136

\section{References (transliterated):}

1. [Ad.] Kakie suda stroit'? // Nedelya. 1898. № 16.

2. [Anonimnyi avtor] $1877=$ dvadtsatipyatiletnie «Novostei» $=1902$ // Novosti. 1902. № 1.

3. [Anonimnyi avtor] Angliiskoe torzhestvo // Nedelya. 1897. № 24.

4. [Anonimnyi avtor] Angliya i Rossiya na Dal'nem Vostoke // Russkie vedomosti. 1898. № 88.

5. [Anonimnyi avtor] Velikie problemy // Kur'er. 1900. № 86. 


\title{
Исторический журнал: научные исследования № 6 (24) • 2014
}

\author{
DOI: $10.7256 / 2222-1972.2014 .6 .14860$
}

6. [Anonimnyi avtor] Vneshnyaya politika Rossii // Novosti. 1900. № 1.

7. [Anonimnyi avtor] Vneshnyaya politika Rossii v 1901 godu // Novosti. 1902. № 1.

8. [Anonimnyi avtor] Voennye deistviya v Kitae // Novosti. 1900. № 255.

9. [Anonimnyi avtor] Inostrannoe obozrenie // Vestnik Evropy. 1895. T. 4. Kn. 7. S. 361-362.

10. [Anonimnyi avtor] Inostrannoe obozrenie // Vestnik Evropy. 1896. T. 1. Kn. 1. S. 397.

11. [Anonimnyi avtor] Inostrannoe obozrenie // Vestnik Evropy. 1898. T. 1. Kn. 1. S. 398-400.

12. [Anonimnyi avtor] Inostrannoe obozrenie // Vestnik Evropy. 1898. T. 5. Kn. 9. S. 380-383.

13. [Anonimnyi avtor] Inostrannoe obozrenie // Vestnik Evropy. 1898. T. 7. Kn. 12. S. 786.

14. [Anonimnyi avtor] Inostrannoe obozrenie // Vestnik Evropy. 1900. T. 1. Kn. 1. S. 382-383.

15. [Anonimnyi avtor] Inostrannoe obozrenie // Vestnik Evropy. 1900. T. 4. Kn. 7. S. 365-375.

16. [Anonimnyi avtor] Inostrannoe obozrenie // Vestnik Evropy. 1900. T. 5. Kn. 9. S. 346-358.

17. [Anonimnyi avtor] Inostrannoe obozrenie // Vestnik Evropy. 1900. T. 7. Kn. 12. S. 802-807.

18. [Anonimnyi avtor] Inostrannoe obozrenie // Vestnik Evropy. 1901. T. 2. Kn. 4. S. 823-829.

19. [Anonimnyi avtor] Inostrannoe obozrenie // Vestnik Evropy. 1902. T. 1. Kn. 1. S. 378-379.

20. [Anonimnyi avtor] Inostrannoe obozrenie // Russkaya mysl'. 1896. Kn. 10. S. 218.

21. [Anonimnyi avtor] Inostrannoe obozrenie // Russkaya mysl'. 1896. Kn. 11. S. 238.

22. [Anonimnyi avtor] Inostrannoe obozrenie // Russkie vedomosti. 1896. № 1.

23. [Anonimnyi avtor] Inostrannoe obozrenie // Russkie vedomosti. 1898. № 1.

24. [Anonimnyi avtor] Inostrannye izvestiya // Kur'er. 1900. № 121.

25. [Anonimnyi avtor] Inostrannye izvestiya // Kur'er. 1902. № 43.

26. [Anonimnyi avtor] Inostrannye izvestiya // Russkie vedomosti. 1898. № 87.

27. [Anonimnyi avtor] Inostrannye izvestiya // Russkie vedomosti. 1898. № 253.

28. [Anonimnyi avtor] Inostrannye izvestiya // Russkie vedomosti. 1898. № 276.

29. [Anonimnyi avtor] Inostrannye izvestiya // Russkie vedomosti. 1899. № 307.

30. [Anonimnyi avtor] Inostrannye izvestiya // Russkie vedomosti. 1900. № 148.

31. [Anonimnyi avtor] Inostrannye izvestiya // Russkie vedomosti. 1900. № 173.

32. [Anonimnyi avtor] Inostrannye izvestiya // Russkie vedomosti. 1902. № 30.

33. [Anonimnyi avtor] Kitai i evropeiskie derzhavy. Kitai i Angliya // Russkie vedomosti. 1900. № 230.

34. [Anonimnyi avtor] Material bez zagolovka // Kur'er. 1899. № 68.

35. [Anonimnyi avtor] Material bez zagolovka // Kur'er. 1900. № 149.

36. [Anonimnyi avtor] Material bez zagolovka // Novosti. 1900. № 298.

37. [Anonimnyi avtor] Material bez zagolovka // Russkie vedomosti. 1899. № 112.

38. [Anonimnyi avtor] O chem pishut // Kur'er. 1900. № 160.

39. [Anonimnyi avtor] O chem pishut // Kur'er. 1900. № 172.

40. [Anonimnyi avtor] Peredovaya stat'ya // Kur'er. 1897. № 31.

41. [Anonimnyi avtor] Peredovaya stat'ya // Russkie vedomosti. 1898. № 65.

42. [Anonimnyi avtor] Peredovaya stat'ya // Russkie vedomosti. 1898. № 85.

43. [Anonimnyi avtor] Peredovaya stat'ya // Russkie vedomosti. 1898. № 150.

44. [Anonimnyi avtor] Peredovaya stat'ya // Russkie vedomosti. 1898. № 223.

45. [Anonimnyi avtor] Peredovaya stat'ya // Russkie vedomosti. 1899. № 70.

46. [Anonimnyi avtor] Peredovaya stat'ya // Russkie vedomosti. 1900. № 159.

47. [Anonimnyi avtor] Politicheskie izvestiya // Nedelya. 1895. № 17.

48. [Anonimnyi avtor] Politicheskie izvestiya // Nedelya. 1898. № 14.

49. [Anonimnyi avtor] Politicheskie izvestiya // Nedelya. 1901. № 1.

50. [Anonimnyi avtor] Politicheskie izvestiya // Novoe delo. 1901. № 2. S. 41.

51. [Anonimnyi avtor] Politicheskie izvestiya // Novoe delo. 1902. № 6. S. 168-169.

52. [Anonimnyi avtor] Politicheskoe obozrenie // Kur'er. 1897. № 31.

53. [Anonimnyi avtor] Politicheskoe obozrenie // Kur'er. 1898. № 5.

54. [Anonimnyi avtor] Politicheskoe obozrenie // Kur'er. 1898. № 86.

55. [Anonimnyi avtor] Politicheskoe obozrenie // Kur'er. 1898. № 93.

56. [Anonimnyi avtor] Politicheskoe obozrenie // Kur'er. 1898. № 102.

57. [Anonimnyi avtor] Politicheskoe obozrenie // Kur'er. 1898. № 129.

58. [Anonimnyi avtor] Politicheskoe obozrenie // Kur'er. 1898. № 206.

59. [Anonimnyi avtor] Politicheskoe obozrenie // Kur'er. 1898. № 215.

60. [Anonimnyi avtor] Politicheskoe obozrenie // Kur'er. 1898. № 335.

61. [Anonimnyi avtor] Politicheskoe obozrenie // Kur'er. 1899. № 59.

62. [Anonimnyi avtor] Politicheskoe obozrenie // Kur'er. 1899. № 110.

63. [Anonimnyi avtor] Politicheskoe obozrenie // Kur'er. 1899. № 113.

64. [Anonimnyi avtor] Politicheskoe obozrenie // Kur'er. 1900. № 59.

65. [Anonimnyi avtor] Politicheskoe obozrenie // Kur'er. 1900. № 64. 
66. [Anonimnyi avtor] Politicheskoe obozrenie // Kur'er. 1900. № 147.

67. [Anonimnyi avtor] Polozhenie del v Kitae // Russkie vedomosti. 1898. № 118.

68. [Anonimnyi avtor] Polozhenie del na krainem Vostoke // Russkie vedomosti. 1899. № 301.

69. [Anonimnyi avtor] Russkaya pechat' // Novosti. 1895. № 161.

70. [Anonimnyi avtor] Russkaya pechat' // Novosti. 1900. № 154.

71. [Anonimnyi avtor] Sankt-Peterburg // Novosti. 1895. № 94.

72. [Anonimnyi avtor] Sankt-Peterburg // Novosti. 1895. № 101.

73. [Anonimnyi avtor] Sankt-Peterburg // Novosti. 1895. № 102.

74. [Anonimnyi avtor] Sankt-Peterburg // Novosti. 1895. № 121.

75. [Anonimnyi avtor] Sankt-Peterburg // Novosti. 1895. № 257.

76. [Anonimnyi avtor] Sankt-Peterburg // Novosti. 1895. № 274.

77. [Anonimnyi avtor] Sankt-Peterburg // Novosti. 1895. № 286.

78. [Anonimnyi avtor] Sankt-Peterburg // Novosti. 1895. № 289.

79. [Anonimnyi avtor] Sankt-Peterburg // Novosti. 1895. № 299.

80. [Anonimnyi avtor] Sankt-Peterburg // Novosti. 1895. № 357.

81. [Anonimnyi avtor] Sankt-Peterburg // Novosti. 1896. № 235.

82. [Anonimnyi avtor] Sankt-Peterburg // Novosti. 1897. № 219.

83. [Anonimnyi avtor] Sankt-Peterburg // Novosti. 1897. № 288.

84. [Anonimnyi avtor] Sankt-Peterburg // Novosti. 1897. № 309.

85. [Anonimnyi avtor] Sankt-Peterburg // Novosti. 1897. № 310.

86. [Anonimnyi avtor] Sankt-Peterburg // Novosti. 1897. № 331.

87. [Anonimnyi avtor] Sankt-Peterburg // Novosti. 1897. № 342.

88. [Anonimnyi avtor] Sankt-Peterburg // Novosti. 1897. № 344.

89. [Anonimnyi avtor] Sankt-Peterburg // Novosti. 1897. № 345.

90. [Anonimnyi avtor] Sankt-Peterburg // Novosti. 1897. № 356.

91. [Anonimnyi avtor] Sankt-Peterburg // Novosti. 1898. № 4.

92. [Anonimnyi avtor] Sankt-Peterburg // Novosti. 1898. № 79.

93. [Anonimnyi avtor] Sankt-Peterburg // Novosti. 1898. № 82.

94. [Anonimnyi avtor] Sankt-Peterburg // Novosti. 1898. № 85.

95. [Anonimnyi avtor] Sankt-Peterburg // Novosti. 1898. № 17.

96. [Anonimnyi avtor] Sankt-Peterburg // Novosti. 1899. № 298.

97. [Anonimnyi avtor] Sankt-Peterburg // Novosti. 1899. № 30.

98. [Anonimnyi avtor] Sankt-Peterburg // Novosti. 1899. № 359.

99. [Anonimnyi avtor] Sankt-Peterburg // Novosti. 1900. № 31.

100. [Anonimnyi avtor] Sankt-Peterburg // Novosti. 1900. № 149.

101. [Anonimnyi avtor] Sankt-Peterburg // Novosti. 1900. № 155.

102. [Anonimnyi avtor] Sankt-Peterburg // Novosti. 1900. № 166.

103. [Anonimnyi avtor] Sankt-Peterburg // Novosti. 1900. № 197.

104. [Anonimnyi avtor] Sankt-Peterburg // Novosti. 1900. № 291.

105. [Anonimnyi avtor] Sankt-Peterburg // Novosti. 1900. № 311.

106. [Anonimnyi avtor] Sankt-Peterburg // Novosti. 1901. № 32.

107. [Anonimnyi avtor] Sankt-Peterburg // Novosti. 1901. № 204.

108. [Anonimnyi avtor] Sankt-Peterburg // Novosti. 1901. № 350.

109. [Anonimnyi avtor] Sankt-Peterburg // Novosti. 1902. № 31.

110. [Anonimnyi avtor] Sankt-Peterburg // Novosti. 1902. № 33.

111. [Anonimnyi avtor] Sankt-Peterburg // Novosti. 1902. № 38.

112. [Anonimnyi avtor] Sankt-Peterburg // Novosti. 1902. № 43.

113. [Anonimnyi avtor] Sobytiya v Kitae // Kur'er. 1900. № 168.

114. [Anonimnyi avtor] Sobytiya v Kitae // Kur'er. 1900. № 171.

115. [Anonimnyi avtor] Chernye tochki // Nedelya. 1895. № 29.

116. [Anonimnyi avtor] Shakh i mat // Novosti. 1898. № 85.

117. [Anonimnyi avtor] Eskadry derzhav na Dal'nem Vostoke // Russkie vedomosti. 1898. № 78.

118. [Anonimnyi korrespondent] Novyi troistvennyi soyuz // Kur'er. 1900. № 175.

119. [Anonimnyi korrespondent] Telegraficheskie izvestiya. Berlin (ot nashego korrespondenta) // Russkie vedomosti. 1901 . № 62.

120. [P. K.] Bor'ba russkoi i amerikanskoi promyshlennosti na aziatskikh rynkakh v 1897 g. // Kur'er. 1898. № 272.

121. [Politik] Sblizhenie mezhdu Germaniei i Soedinennymi Shtatami // Kur'er. 1902. № 49.

122. [Strannik] Podkhlestyvateli obshchestvennogo mneniya // Kur'er. 1900. № 155.

123. [Tek] Pis'ma iz Pekina // Novosti. 1897. № 58.

124. [Tek] Pis'ma s Dal'nego Vostoka // Novosti. 1897. № 357.

125. [Kh.] Po povodu sobytii v Kitae // Kur'er. 1900. № 174. 


\title{
Исторический журнал: научные исследования № 6 (24) 2014
}

\author{
DOI: $10.7256 / 2222-1972.2014 .6 .14860$
}

126. [Z.] London (ot nashego korrespondenta) // Novosti. 1895. № 109.

127. Anuchin D. N. Kitai i evropeiskie derzhavy // Russkie vedomosti. 1900. № 248.

128. Bogdanovich L. A. Na krainem Vostoke // Kur'er. 1900. № 168.

129. Bogdanovich L. A. Pravda o revolyutsii na Filippinakh // Kur'er. 1900. № 93.

130. Vasilevskii I. F. Peterburgskie nabroski (Chto pishut teper' v Evrope po povodu Anglii?) // Russkie vedomosti. 1899 . № 343.

131. Vereshchagin V. Listki iz zapisnoi knizhki // Novosti. 1900. № 245.

132. Vereshchagin V. Mogushchestvenna li Angliya? // Novosti. 1896. № 15.

133. Gol'tsev V. A. 1895 god v politicheskom otnoshenii // Russkaya mysl'. 1896. Kn. 1. S. 243-250.

134. Gol'tsev V. A. 1899 god v politicheskom otnoshenii // Russkaya mysl'. 1900. Kn. 1. S. 221-226.

135. Gol'tsev V. A. 1900 god v politicheskom otnoshenii // Russkaya mysl'. 1901. Kn. 1. S. 208-214.

136. Gol'tsev V. A. Inostrannoe obozrenie // Russkaya mysl'. 1898. Kn. 4. S. 178-179.

137. Gol'tsev V. A. Inostrannoe obozrenie // Russkaya mysl'. 1898. Kn. 6. S. 193.

138. Gol'tsev V. A. Inostrannoe obozrenie // Russkaya mysl'. 1898. Kn. 9. S. 233.

139. Gol'tsev V. A. Inostrannoe obozrenie // Russkaya mysl'. 1899. Kn. 2. S. 172.

140. Gol'tsev V. A. Inostrannoe obozrenie // Russkaya mysl'. 1899. Kn. 5. S. 185.

141. Gol'tsev V. A. Inostrannoe obozrenie // Russkaya mysl'. 1899. Kn. 6. S. 225.

142. Gol'tsev V. A. Inostrannoe obozrenie // Russkaya mysl'. 1900. Kn. 6. S. 211-212.

143. Gol'tsev V. A. Inostrannoe obozrenie // Russkaya mysl'. 1900. Kn. 8. S. 242.

144. Gol'tsev V. A. Inostrannoe obozrenie // Russkaya mysl'. 1900. Kn. 11. S. 273-274.

145. Gol'tsev V. A. Inostrannoe obozrenie // Russkaya mysl'. 1901. Kn. 2. S. 201-202.

146. Gol'tsev V. A. Inostrannoe obozrenie // Russkaya mysl'. 1902. Kn. 3. S. 222-223.

147. Gol'tsev V. A. Mysli vslukh // Kur'er. 1900. № 183.

148. Iollos G. B. Inostrannye izvestiya. Berlin // Russkie vedomosti. 1898. № 33.

149. Korsakov V. V. Evropeiskie shkoly v Kitae // Russkie vedomosti. 1898. № 138.

150. Kuznetsov P. Britanskii imperializm // Novosti. 1897. № 206.

151. Modestov V. Mogushchestvo Anglii // Novosti. 1896. № 14.

152. Obolenskii E. Mirovye interesy v Kitae // Novosti. 1900. № 161.

153. Rapaport S. Rabochaya Angliya // Nedelya. 1897. № 32.

154. Telegrammy // Kur'er. 1902. № 32.

155. Telegrammy // Kur'er. 1902. № 33.

156. Telegraficheskie izvestiya // Russkie vedomosti. 1895. № 288.

157. Telegraficheskie izvestiya // Russkie vedomosti. 1901. № 148.

158. Telegraficheskie izvestiya // Russkie vedomosti. 1902. № 50.

159. Engel'gardt M. Rossiya i Angliya protiv Germanii // Novosti. 1900. № 226.

160. Engel'gardt M. Starye soperniki i novye pretendenty // Novosti. 1900. № 233.

161. Yuzhakov S. N. Dnevnik zhurnalista // Russkoe bogatstvo. 1897. Kn. 8. S. 106-131.

162. Yuzhakov S. N. Politika // Russkoe bogatstvo. 1898. Kn. 2. S. 107-131.

163. Yuzhakov S. N. Politika // Russkoe bogatstvo. 1898. Kn. 8. S. 233-235.

164. Yuzhakov S. N. Politika // Russkoe bogatstvo. 1900. Kn. 11. S. 155-156.

165. Yuzhakov S. N. Politika // Russkoe bogatstvo. 1901. Kn. 5. S. 144-153.

166. Yuzhakov S. N. Politika // Russkoe bogatstvo. 1902. Kn. 2. S. 121-132.

167. Yuzhakov S. N. Politika. 1898 god // Russkoe bogatstvo. 1899. Kn. 1. S. 101-117.

168. Yuzhakov S. N. Politika. God 1900 // Russkoe bogatstvo. 1900. Kn. 12. S. 204-206.

169. Yuzhakov S. N. Politika. Pervyi god molodogo veka // Russkoe bogatstvo. 1901. Kn. 12. S. 118-136 